\title{
Daisies Down Under: \\ Review of the state of taxonomy and phylogenetics of native Australian Asteraceae
}

\author{
Alexander N. Schmidt-Lebuhn' ${ }^{(0)}$ \\ ' CSIRO, Centre for Australian National Biodiversity Research, Clunies Ross Street, Canberra ACT 260 I, Australia; alexander.s-l@csiro.au
}

DOI: http://dx.doi.org/l 0.53875/capitulum.01.2.03

\begin{abstract}
Because of the long history of isolation of Australia, the continent is home to a unique diversity of Asteraceae. The native daisy flora of ca. I, I 05 species is dominated by Gnaphalieae, Astereae, Senecioneae, and Inuleae, whereas other globally diverse tribes such as Cardueae, Cichorieae, or Heliantheae are poorly represented. The last ca. forty years have seen taxonomic revisions of most major genera of Australian Asteraceae with the notable exceptions of Olearia and Ozothamnus. Despite this, current genus-level classification is often based on few morphological characters traditionally considered important (e.g., presence of pappus or capitulum scales). It is therefore likely that many genera are non-monophyletic in their current circumscriptions, as recently confirmed (e.g., for Coronidium, Olearia, and Ozothamnus). As of writing, phylogenetic studies of several other taxa are being conducted or under review. Once phylogenetic relationships have been resolved, the research focus will shift to understanding the evolution of the continental Asteraceae flora in time and space and the impact of Australia's aridification and key evolutionary and biogeographic events on patterns of diversification.
\end{abstract}

Keywords: Australia, phylogenetics, taxonomy, review

\section{INTRODUCTION}

The Australian Asteraceae comprise ca. I,I05 formally described native species, plus ca. 354 introduced species (Australian Plant Census, https:// biodiversity.org.au/nsl/services/search/taxonomy, accessed June 202I). The continent is dominated by only four of the more than 40 tribes of the family (Figure I). The vast majority of the native Asteraceae flora belongs to tribes Gnaphalieae Cass. ex Lecoq \& Juillet (510 spp., Figure 2), Astereae Cass. (334 spp., Figure 5), Senecioneae Cass. (I03 spp.), and Inuleae Cass. (65 spp., incl. Plucheae (Cass. ex Dum.) A.Anderb.), whereas the other globally diverse tribes Cardueae Cass., Vernonieae Cass., Cichorieae Lam. \& DC., Anthemideae Cass., Eupatorieae Cass., and Heliantheae Cass. are represented with only few species (e.g., Heliantheae, 25 spp; Cichorieae, 23 spp.).
All tribes except the two largest have been treated in the Flora of Australia series (Wilson, 2015), meaning, conversely, that ca. $80 \%$ of the diversity are yet to be included in a flora treatment at the national level. Although the Australian Plant Census and Australian Plant Name Index (https://biodiversity. org.au/nsl/services/search/names) provide up-todate taxonomic and nomenclatural information, other details such as descriptions and keys are consequently scattered across an enormous number of papers in journals published predominantly by state herbaria and state floras of varying age.

The present review summarizes the state of knowledge of taxonomy, molecular phylogenetics, and biogeography of Australian Asteraceae with a focus on the most important publications of the last ca. forty years, i.e., to the exclusion of some papers 


\section{Back o' Bourke}

The genus Calotis (Astereae) exhibits

a great diversity of fruit morphologies. The fruit

of this arid zone species has both numerous barbs

and two broad, woolly wings. Here in full glory with a

background iconic of the the red continent, at the very

edge of the Great Australian desert.
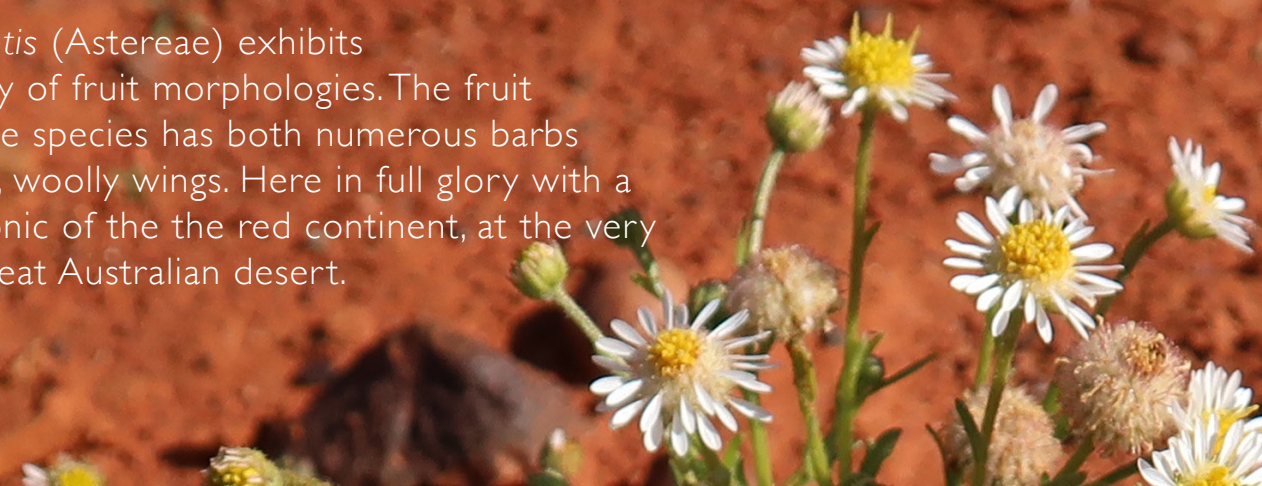

$\lim _{3} \frac{3}{3}$

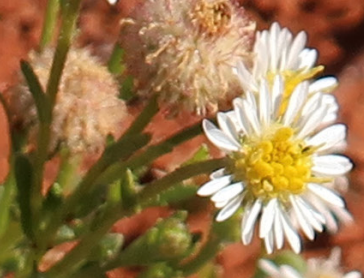

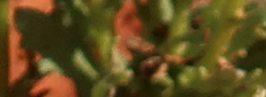

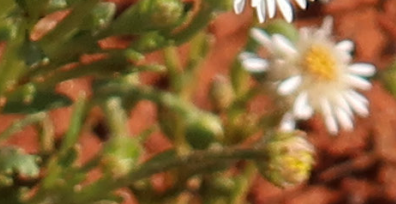

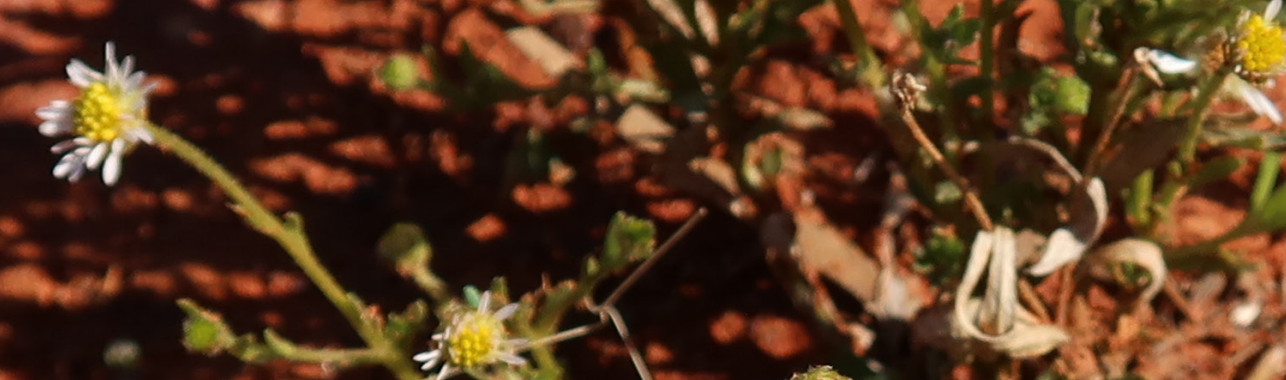

$-\infty .2 x+2050$

$(1,2,7)$

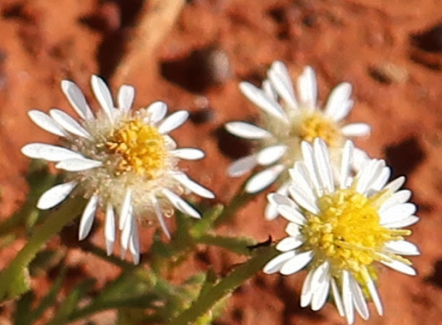

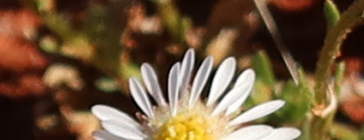

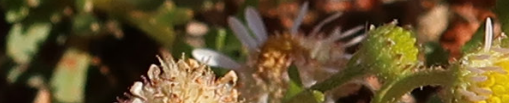

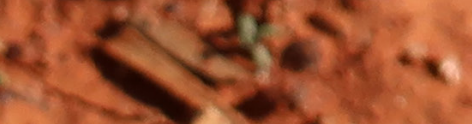

$\cos 2$

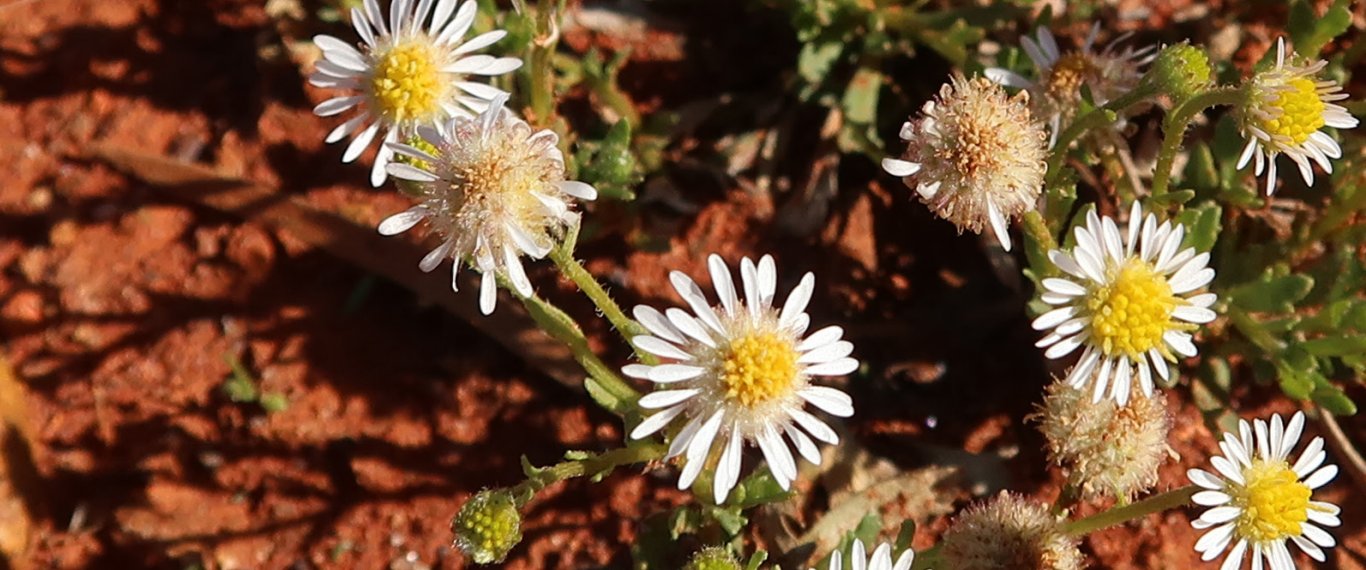

(1) ${ }^{3}{ }^{3}$

3.

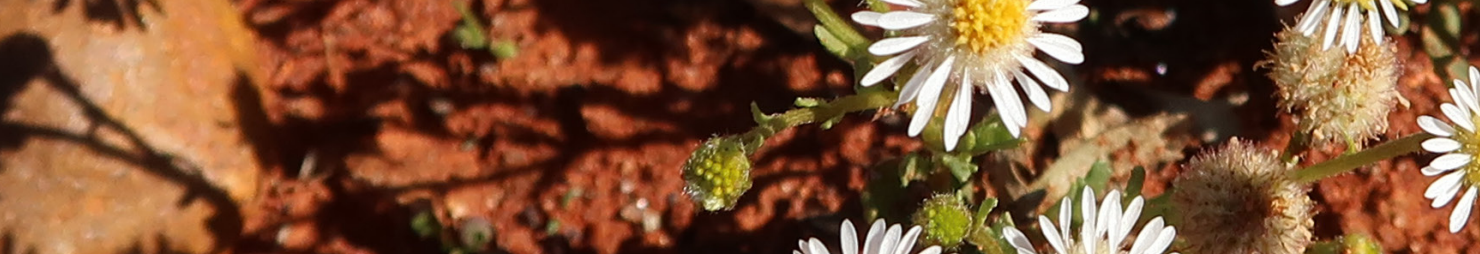

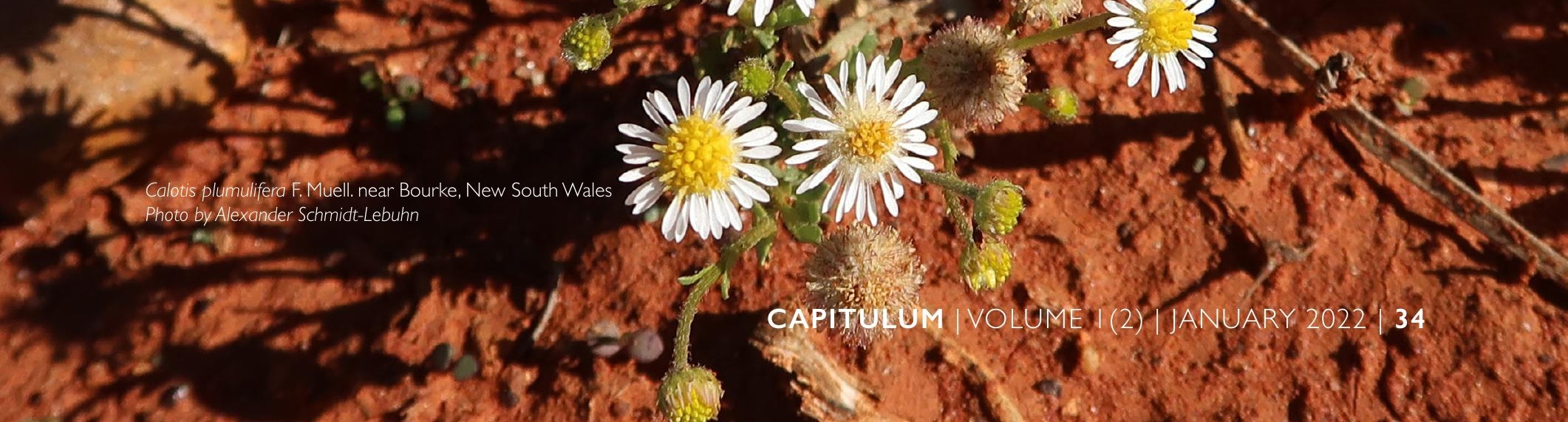

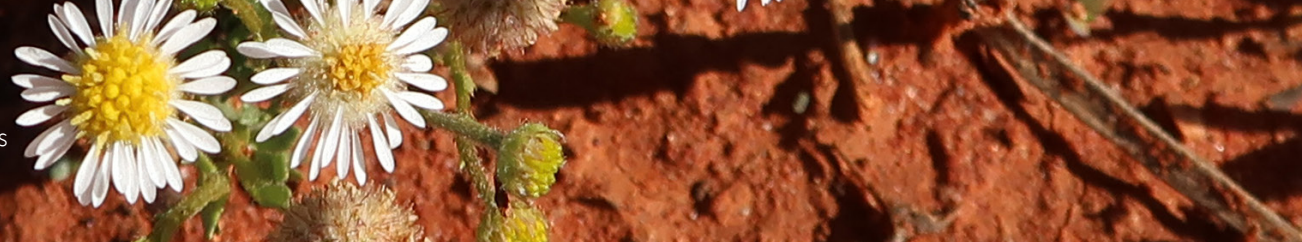


presenting only new species and combinations or revisions of very small genera. Its purpose is to (I) serve as a guide to the existing literature, and (2) identify gaps for future research.

\section{GNAPHALIEAE}

Gnaphalieae are the largest tribe of Asteraceae in Australia. Their centres of diversity are in the southwest and the southeast of the continent, including the southeastern mountain ranges and Tasmania. They comprise significant parts of the vegetation in the subalpine and alpine zones and, transiently, in the arid zone of the continent, where carpets of ephemeral species appear after strong rainfall events (Figure 2A).

Over the last ca. forty years, the genus level classification of Australian Gnaphalieae has changed considerably. The changes were prompted to a great degree by the realization that the genera Helipterum DC. and Helichrysum Mill., to which many of the species previously belonged, were polyphyletic (Anderberg, 1991).

Species formerly classified as Helichrysum were accommodated in the newly described or reinstated genera Argentipallium Paul G.Wilson and Anemocarpa Paul G.Wilson (Wilson, 1992c), Coronidium Paul G.Wilson (Wilson, 2008), Leiocarpa Paul G.Wilson (Wilson, 200I), Ozothamnus R.Br. (Anderberg, 1991), and Xerochrysum Tzvelev (Bayer, 200I), supplemented by later additions of species (e.g., Walsh, 20I4; Wilson, 2017; Schmidt-Lebuhn et al., 2018). Those formerly in Helipterum have been accomodated in the genera Hyalosperma Steetz (Wilson, 1989), Leucochrysum (A.Cunn. ex DC.) Paul G.Wilson (Wilson, 1992b), and Rhodanthe Lindl. (Wilson, 1992a).

Concurrently, most large and medium-sized genera underwent taxonomic revisions, or at least saw the publication of synopses including identification keys. They include Angianthus J.C.Wendl. and relatives (Short, 1983; Keighery, 2004; Lyons \& Keighery, 2015), Chthonocephalus Steetz (Short, 1990), Cassinia R.Br. and its satellite genera (Orchard, 2004d, 2004c, 2004b, 2004a, 2006; Orchard \& Orchard, 2005, 2009), Calocephalus R.Br. and Gnephosis Cass. (Short, 20I 5), Chrysocephalum Walp. in part (Wilson, 2016), Millotia Cass. (Short, 1995),
Myriocephalus Benth. (Short, 2000), Podolepis Labill. (Jeanes, 20I5, 2020), Rutidosis DC. (Holland, I994, 1999), and Waitzia J.C.Wendl. (Wilson, 1992d). Craspedia G.Forst., a genus of rosette plants with a centre of diversity in alpine areas, has received significant taxonomic attention (Everett \& Doust, 1992a; Everett \& Thompson, 1992; McDougall \& Walsh, 2008; Rozefelds et al., 20 I I; Schmidt-Lebuhn, $20 / 3)$, including the reinstatement of its previously synonymized sister group Pycnosorus Benth. (Everett \& Doust, 1992b).

Apart from Anderberg's cladistic analyses of morphological data (Anderberg, 1990, 1991; Short \& Anderberg, 1995), and excepting a limited number of studies on the delimitation of species, i.e. below the genus level (Dennis \& Walsh, 2010; Ohlsen et al., 20।0; Salas \& Schmidt-Lebuhn, 20।8), none of these changes were supported by formal analysis or explicit consideration of natural groups and synapomorphies. Many generic concepts are consequently based on single character states, e.g. absence or presence of pappus or receptacle scales, suggesting that they may represent apomorphic segregates.

Molecular phylogenies allowing the testing of these concepts remain sparse. The first molecular phylogeny at the tribal level was published by Bayer et al. (2002). More recently, a study using sequence capture data resolved four major lineages, the predominantly annual and arid zone-centred Angianthus clade (Fig. 2A), the shrubby Cassinia clade (Figure 2B; see page 43 ), the Euchiton clade (Figure 2C; Figure 3) largely of cudweed-like and cushion plants, and the predominantly perennial and eastern-temperate Waitzia clade (SchmidtLebuhn \& Bovill, 202I; see page 40). Neither study, however, sampled densely enough to address genus boundaries. Conversely, a molecular phylogeny of Podolepis (Konishi et al., 2000) did not include sufficient potential relatives to test monophyly.

Where studies were designed to test genus boundaries, they generally confirmed the problems described above. All genera of the Cassinia clade, including the large genus Cassinia itself, are nested in Ozothamnus (Schmidt-Lebuhn \& Constable, 2013); Haeckeria F.Muell. and Odixia Orchard are epappose Cassinia and Ozothamnus, respectively, and Cassinia is Ozothamnus with receptacle scales. 


\section{$\left\{\begin{array}{c}\text { OOMPOSITAE } \\ \text { Of AUSTRALIA }\end{array}\right.$}

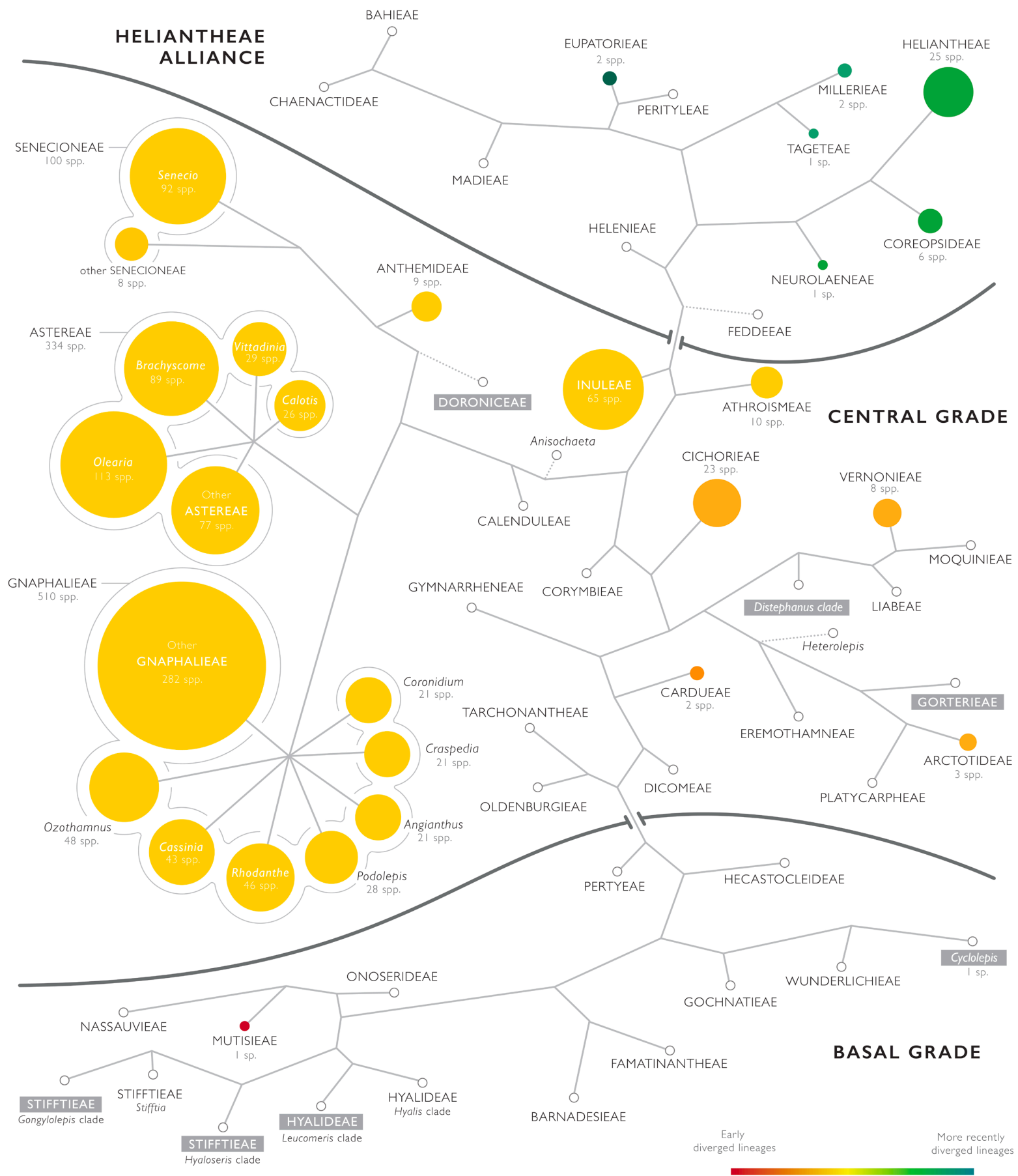

Figure I. Diversity of native Australian Compositae (Asteraceae) plotted on current classification (Susanna et al., 2020). Circle size is indicative of species number; empty circles indicate taxa absent as natives in the continent; only genera with at least twenty native species are shown. 
Of the three species groups of Coronidium, two are paraphyletic to Xerochrysum, and the third is unrelated (Schmidt-Lebuhn et al., 2015). Comprehensive taxonomic revisions and phylogenetic analyses of the two genera have recently been completed (Tim Collins, ms. in prep.; Figure 4), but the affinities of the Coronidium scorpioides group are still unclear. One species of Leucochrysum was found to be sister to Waitzia, which was not recognized previously because Watzia had been defined by the beak of the cypsela (Weber \& Schmidt-Lebuhn, 20I5). It is to be expected that similar results will be obtained from phylogenetic analyses of other genera. Current work focuses on the Angianthus and Euchiton clades, which have so far received the least attention (Schmidt-Lebuhn, unpubl. data).

An interesting aspect of some arid zone taxa in the Angianthus clade is the impact of breeding systems on species concepts. There are several pairs of otherwise indistinguishable populations differing only in their outcrossing versus asexual reproduction, in the latter case diagnosable by smaller anthers with an order of magnitude fewer pollen grains. Often the asexual forms occupy much larger ranges, presumably because they need only a single seed to establish a new population. The pairs have been recognized as separate species (Short, 1985, 1986), but the species concept underlying this taxonomy was not made explicit.

\section{ASTEREAE}

Australian Astereae show a wide diversity of morphologies ranging from minuscule ephemeral herbs to treelets prized by woodworkers (Olearia argophylla (Labill.) F. Muell. ex Benth.). Their centre of diversity is in the temperate southeast of the continent, but they are found across most major ecological zones.

Although considerable revisionary work has been conducted over recent decades, the tribe has seen much less dramatic taxonomic changes than the Gnaphalieae. The large herbaceous genus Brachyscome Cass. (Figure 5C) has recently been revised, and another segregate, Roebuckiella P.S.Short, was created (Short, 20I4a, 20l4b), adding to the growing number of small satellite genera including Allittia P.S.Short, Hullsia P.S.Short, and Pembertonia P.S.Short. The widespread southern hemisphere genus Lagenophora Cass. likewise has an up-to-date treatment (Wang \& Bean, 2019), although the status of potentially phylogenetically nested Solenogyne Cass. remains unclear, as has Camptacra N.T.Burb. (Bean, 2020b).

Older but still comparatively recent taxonomic revisions are available for Minuria DC. (Lander \& Barry, 1980) and Vittadinia A.Rich. (Burbidge, 1982). Calotis R.Br. (see page 34), which is of interest for its diverse pappus morphologies ranging from standard bristles to barbed spines, has not been reviewed since Davis ( 1952).

Comprehensive treatments are lacking for other medium-sized genera, although Celmisia Cass. (Figure 5D), which in Australia constitutes an important part of the alpine vegetation, saw the addition of three new species and one new combination (Gray \& Given, 1999), and a group of mostly alpine species previously classified as Erigeron L. has been segregated as Pappochroma Raf. (Nesom, 1998) (Figure 5B).

In its current circumscription, Olearia Moench. (Figure 5A) is with ca. II 3 species the largest genus of Asteraceae in Australia, but, perhaps because of its size, no monographic treatment is available. Various new species have been described in recent years (Walsh, 2004; Bean \& Mathieson, 2015; Messina \& Walsh, 2019; Bean, 2020a). The most detailed work was conducted on Olearia section Asterotriche Benth. using both morphological (Messina et al., 20/3) and molecular data (Messina et al., 20।4).

Although several of the smaller genera of Australian Astereae are very likely natural units, the largest of them, Olearia and Brachyscome, are more problematic. Molecular phylogenetic studies of Olearia and relatives suggested that the genus is non-monophyletic (Cross et al., 2002; Wagstaff et al., $20 \mathrm{II}$ ). A recent Ph.D. project in New Zealand on the Celmisia group confirmed this and also found Celmisia to be non-monophyletic, which may have implications for the Australian members of that genus (Patricio Rodrigo Saldivia Pérez, unpubl. data). Recently the splitting of Olearia into ten new genera was suggested (Nesom, 2020) with reference to the phylogeny of Cross et al. (2002), but this new taxonomy has not yet found widespread acceptance and may at any rate have to be reconsidered in the light of Saldivia Pérez' results. 

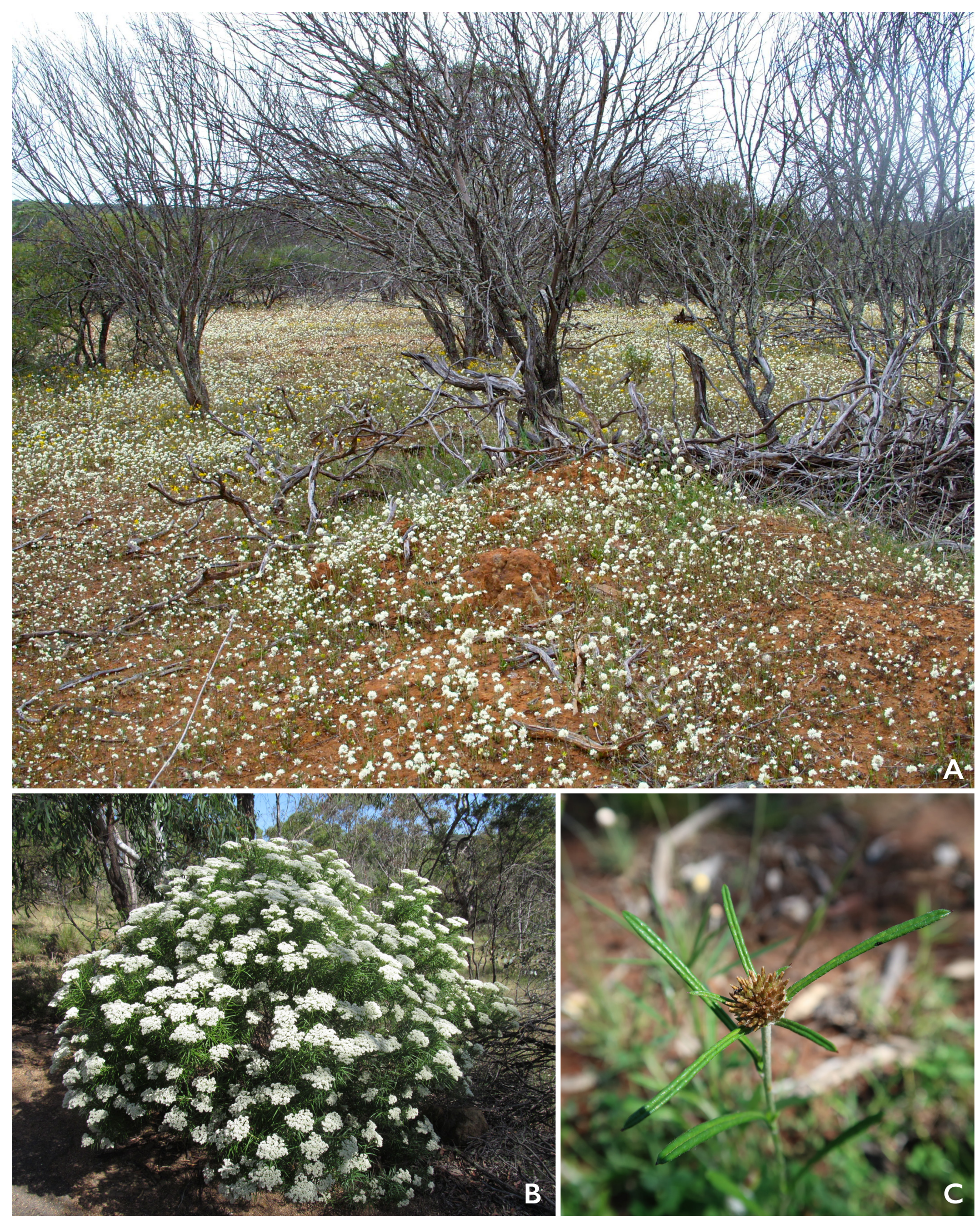

Figure 2. Australian Gnaphalieae. A. Cephalipterum drummondii A.Gray mass-flowering in Western Australia in spring. B. Cassinia longifolia R.Br., a representative of the woody Cassinia group. C. Euchiton sphaericus (Willd.) Holub in the Australian Capital Territory. Photos: A.N. Schmidt-Lebuhn. 


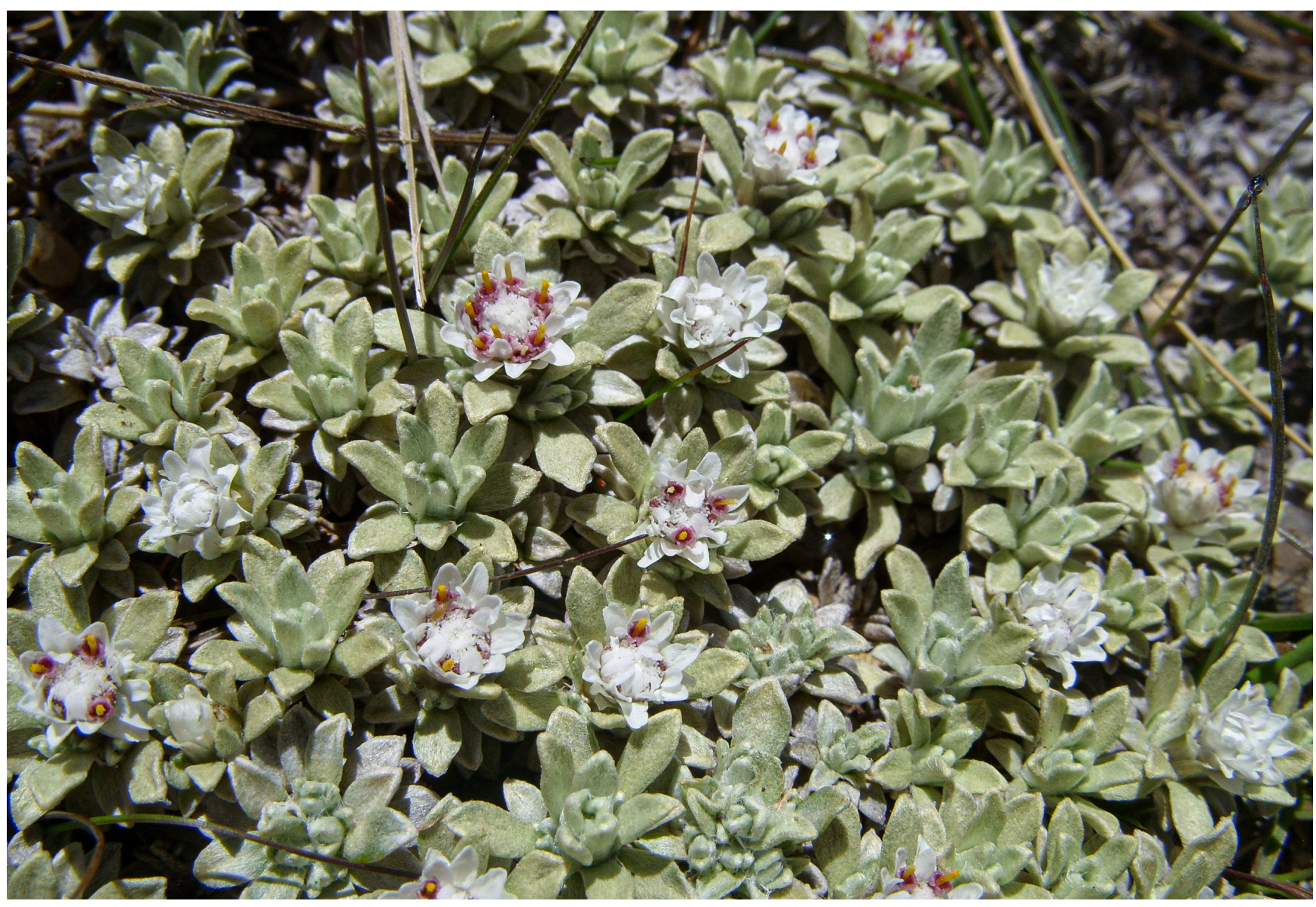

Figure 3. The Euchiton clade of Australian Gnaphalieae contains several alpine cushion plants, such as this Ewartia. Ewartia nubigena (F. Muell.) Beauverd in Kosciuszko National Park, New South Wales. Photo: A.N. Schmidt-Lebuhn.

A molecular phylogeny of Brachyscome has long been available (Denda et al., 1999). Although its sampling was limited compared to the size of the genus, the results already demonstrated that Allittia, Pembertonia, and Roebuckiella are deeply nested in Brachyscome and constitute apomorphic segregates, even before they were in fact segregated. A more broadly sampled phylogenetic study of Brachyscome has recently been completed (Megan Hirst, unpubl. data.).

Phylogenies of the remaining genera, where they exist, provide little evidence on generic delimitation. A phylogeny of the Vittadinia group suggested that Minuria may be non-monophyletic and was unable to resolve Vittadinia and Tetramolopium Nees as entirely reciprocally monophyletic, but the results had limited resolution and support (Lowrey et al., 200I). A study of Calotis showed little resolution at the base of the genus and included only two outgroup samples (Watanabe et al., 2006).

\section{SENECIONEAE}

The vast majority of Australian Senecioneae species belong to Senecio L. sens.str. (Figure 6A), which is most diverse in the temperate southeast of the continent. The most recent, very thorough revision of the genus in Australia led to the description of several new species and recognised seven species groups (Thompson, 2004c, 2004a, 2004b, 2005a, 2005b, 2006).

Few of the species groups, however, were resolved as natural groups in subsequent molecular phylogenies. Ribosomal and chloroplast trees both resolved three clades but showed marked incongruence, suggesting some reticulate evolution and the existence of four Australasian species groups partly defined by chromosome numbers (Liew et al., 2018). Subsequently, several Australian species previously treated as Senecio were found to be only distantly related to that genus, leading to the description of 


\section{Habitat specialists}

Leucochrysum (Gnaphalieae) is only a small genus, but its five species have adapted to very diverse habitats. This adaptive radiation must have been very recent, because four of the species can still be crossed with each other.

The species depicted here is alpine; the others occur, respectively, on red sand in the western part of the arid zone, on heavy soils in the eastern part of the arid zone, in temperate areas along the mountain ranges of eastern Australia, and only on ironstone-sandstone rock pagodas

in a small area near the Blue Mountains.

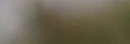

Leucochrysum alpinum (F. Muell.) R.J. Dennis \& N.G. Walsh in Kosciuszko National Park, New South Wales Photo by Alexander Schmidt-Lebuhn 


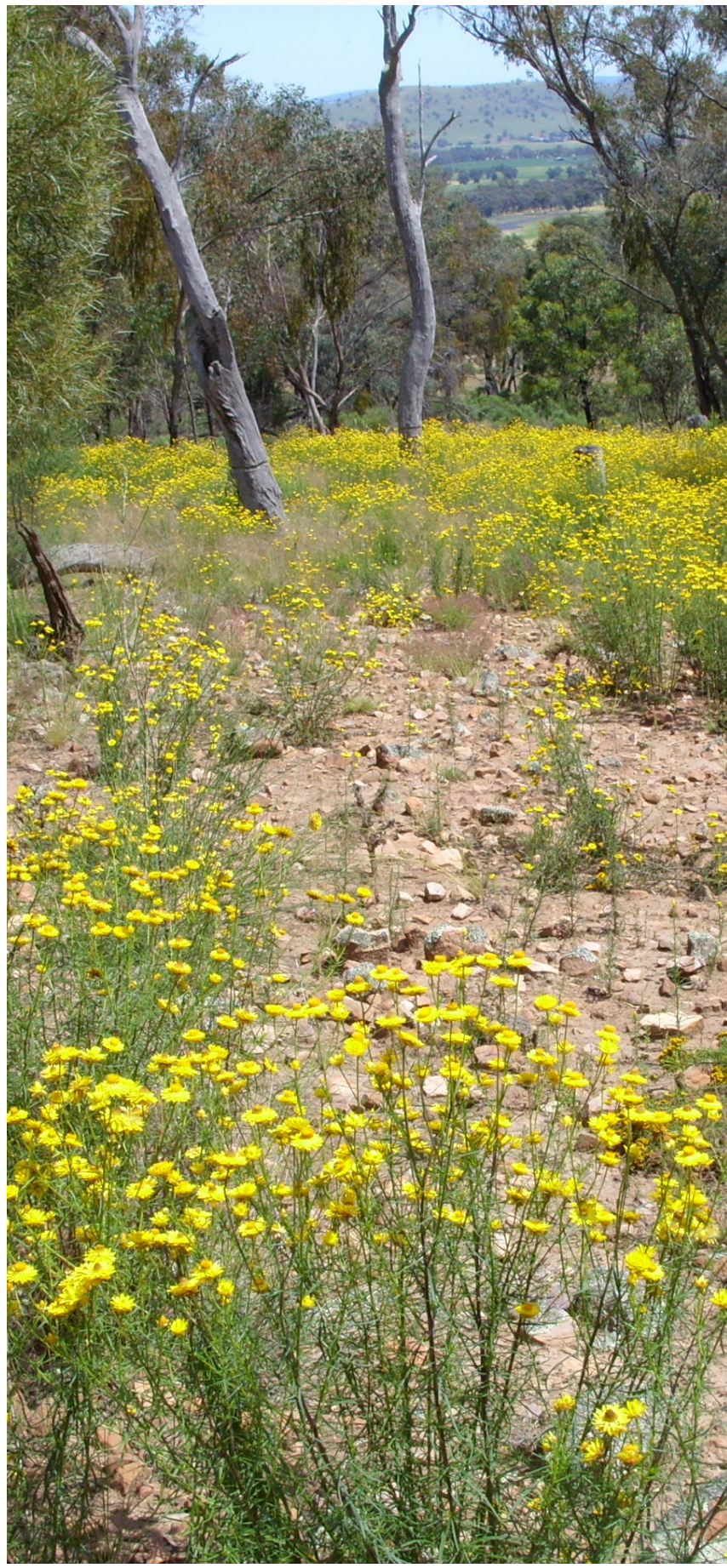

Figure 4. The genus Xerochrysum, commonly called the golden everlastings, is the horticulturally most important group of Australian native Asteraceae. Colorful hybrid variants are cultivated globally as cut-flowers. Xerochrysum viscosum (Sieber ex DC.) R.J.Bayer, mass-flowering in the Australian Capital Territory.

a new genus of alpine rosette plants, Scapisenecio Schmidt-Leb., and the expansion of previously monotypic Lordhowea B.Nord. (Schmidt-Lebuhn et al., 2020).

\section{OTHER TRIBES}

Recent taxonomic treatments exist for most of the larger genera representing other tribes in Australia. Molecular phylogenies are available and well-sampled for some important taxa but entirely absent for others.

In contrast to the top three, the regionally fourth largest tribe, Inuleae, is most diverse in the northern half of the continent. Several genera have been taxonomically revised in recent years, including Pluchea Cass. (Hunger, 1996, 1997; KingJones, 200l; Bean, 20llb, 20l3b), Pterocaulon Elliott sect. Monenteles (Labill.) Kuntze (Bean, 20Ila), Streptoglossa Steetz (Dunlop, |98I), and Sphaeromorphaea DC. and Ethuliopsis F.Muell. (Bean, $2013 a$ ). Australian Blumea DC. was last reviewed in the Flora of Australia (Dunlop \& Orchard, 20 I 5), not in a dedicated monograph. No phylogenetic studies have been published with a focus on diversification in Australia.

Genus limits have been redrawn in Heliantheae, in particular with the segregation of Apowollastonia Orchard (seven Australian species) from Wedelia Jacq. (Orchard, 2013). This new taxonomy was subsequently supported by phylogenetic analysis (Edwards et al., 20|8). Pentalepis F.Muell., with six Australian species, was revised twice in recent decades (Karis et al., 1993; Orchard \& Cross, 20 I2).

Apart from a variety of introduced weeds, two genera of Cichorieae are significant in Australia. The regionally largest is Picris $L$. with $c a$. ten species, all which had for several decades been considered to represent introduced $P$. hieracioides L., which, however, had never established after an early incursion (Holzapfel, 1994). Species delimitation in Australian Microseris D.Don. (Figure 6D) is traditionally controversial, but it is currently considered to comprise three species (Walsh, 20I6). The root tubers of the genus, commonly known as murnong or yam daisy, were an important food source for indigenous people (Gott, 1983).

Anthemideae are represented with only nine species of Cotula L. and Leptinella Cass., part of a southern hemisphere clade of the tribe. Cotula alpina (Hook.f.) Hook.f. (Figure 6B) is nested in Leptinella Cass. (Himmelreich et al., 20I2), as morphologically 

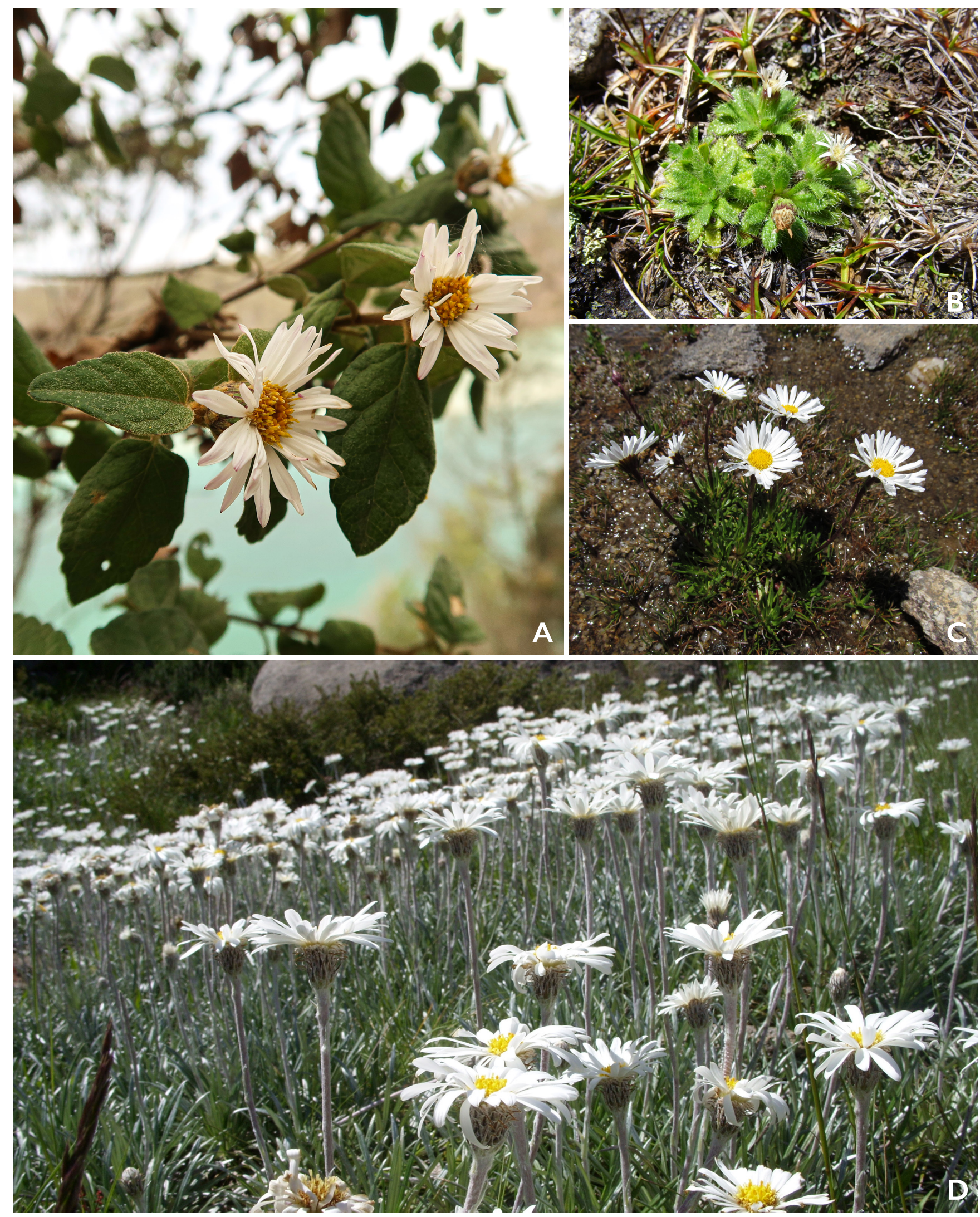

Figure 5. Australian Astereae. A. Olearia tomentosa (J.C.Wendl.) DC., coastal New South Wales. B. Pappochroma setosum (Benth.) G.L.Nesom. C. Brachyscome stolonifera G.L.Davis. D. Celimisa sp. in the alpine zone of Kosciuszko National Park, New South Wales, where Asteraceae constitute ca. $20 \%$ of the vascular flora. Photos: A.N. Schmidt-Lebuhn. 


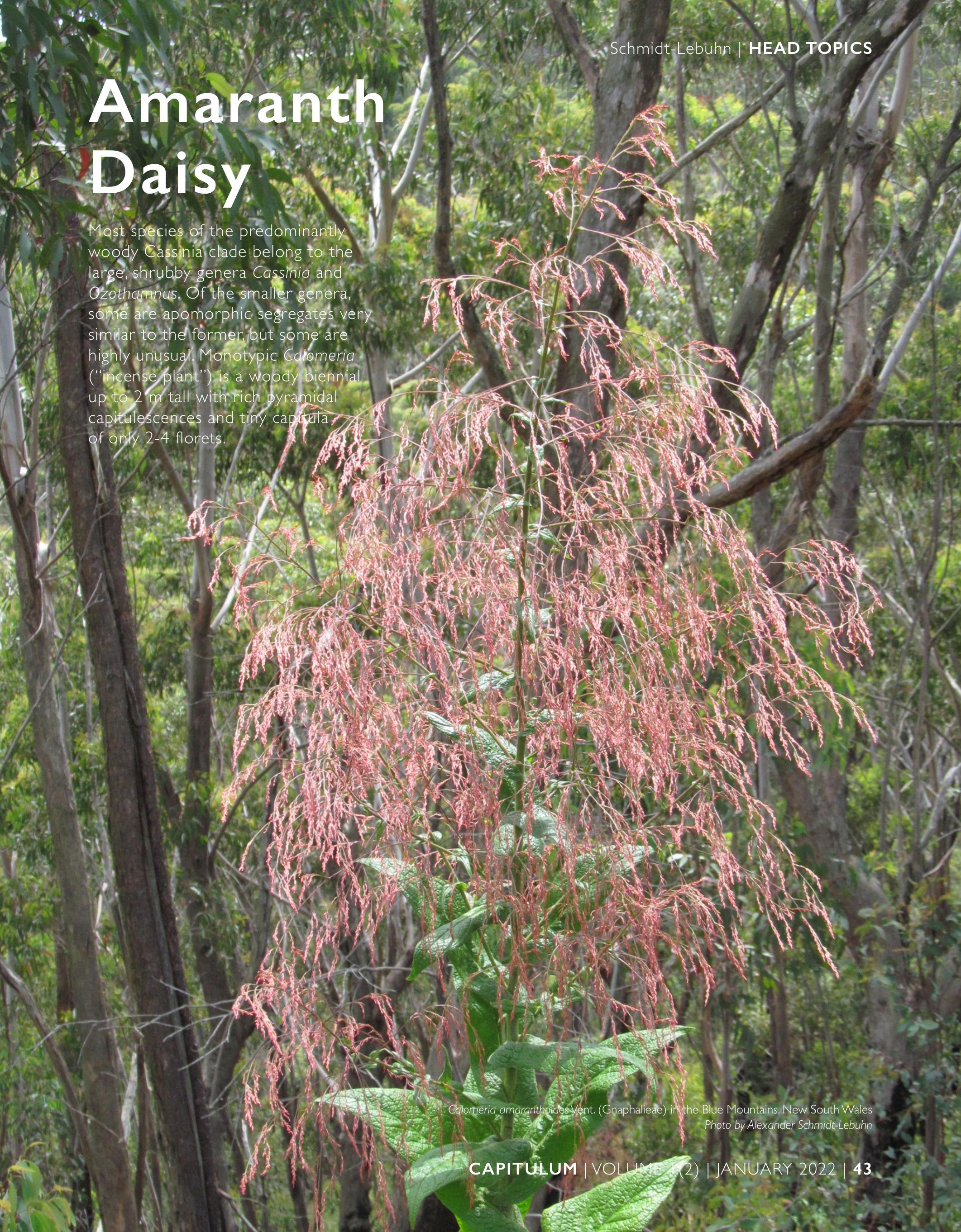



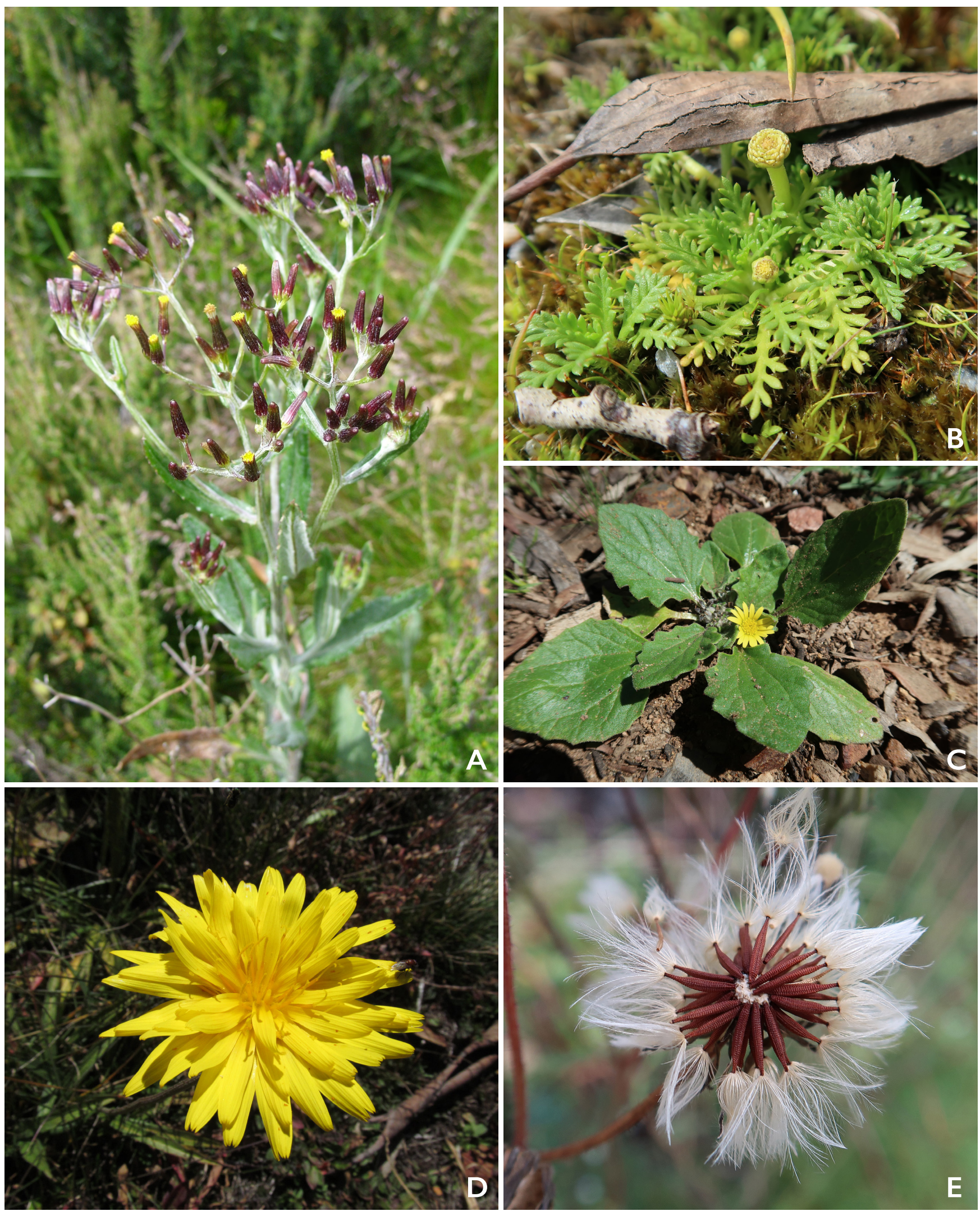

E

Figure 6. A. Senecio gunnii (Hook. f.) Belcher (Senecioneae). B. Cotula alpina (Hook. f.) Hook. f. (Anthemideae), Kosciuszko National Park, New South Wales. C. Cymbonotus sp. (Arctotideae), Australian Capital Territory. D. Microseris lanceolata (Walp.) Sch.Bip. (Cichorieae), New South Wales. E. Fruits of Picris angustifolia DC. (Cichorieae), Namadgi National Park, Australian Capital Territory. Photos: A.N. Schmidt-Lebuhn. 
suggested by its stoloniferous habit, but the species has not yet been transferred.

Centipeda Lour. (Athroismeae) has been studied taxonomically (Walsh, 200I), and phylogenetically (Nylinder et al., 2013). The only Australian genus of Arctotideae, Cymbonotus Cass. (Figure 6C), has been expanded to three species (Holland \& Funk, 2006).

\section{BIOGEOGRAPHY OF AUSTRALIAN ASTERACEAE}

There is no general pattern of biogeographic history across the Australian Asteraceae, as already suggested by the large number of tribes that are present and their enormous differences in species numbers. Despite the long isolation of the continent, numerous natural introductions must have occurred, in some cases across large distances.

With few exceptions in Gnaphalium L. and Pseudognaphalium Kirp., the Australian Gnaphalieae are all part of a single clade, the Australasian clade (Smissen et al., 2020). This informal clade name contrasts with the other clade names in the tribe, which are derived from genus names. This is a consequence of its species richness and splitting into many genera in combination with narrow occurrence in that biogeographic region, whereas the other clades are either small (and thus comfortably named after a single core genus) or widespread. It is likely that the clade is derived from a single dispersal event from southern Africa, perhaps as recent as ca. I 5 MYA (Bergh \& Linder, 2009; Nie et al., 20 I6).

Even in Australasia, and even accounting for oversplitting, few genera of Gnaphalieae are widespread, suggesting that dispersal capability is limited. The Euchiton group (Schmidt-Lebuhn \& Bovill, 202I) is the most mobile, ranging across Australia, New Zealand, New Guinea, and into the Pacific area. Craspedia originated in Australia and dispersed into New Zealand, radiating there into a bewildering array of forms awaiting taxonomic resolution (Ford et al., 2007). Ozothamnus follows the same pattern, with the New Zealand species presumably related to the Tasmanian O. ledifolius (A.Cunn. ex DC.) Hook.f. complex (Breitwieser \& Ward, 1997). Xerochrysum, finally, is found in both Australia and New Guinea; all other genera are endemic.
Senecioneae, in contrast, appear to be highly mobile. Some genera have dispersed to Australia but did not diversify (Arrhenechthites Mattfeld, Gynura Cass.), but, more importantly, the Australasian ribosomal and chloroplast clades of Senecio are nested between various non-Australasian clades (Liew et al., 20l8), suggesting repeated dispersals from different directions followed by diversification. The small woody genera Bedfordia DC. and Centropappus Hook.f. are nested within New Zealand Brachyglottis

J.R.Forst. \& G.Forst. (Wagstaff \& Breitwieser, 2004), suggesting they are derived from a trans-Tasman dispersal. The alpine cushion plants of the genus Abrotanella Cass. have what appears to be a classic Gondwanan distribution, including in southeastern Australia, but clade ages in the genus are too young to be explained by vicariance (Swenson et al., 20 I2).

The recent expansion of Lordhowea to include mainland species resolved the puzzle of the origin of previously isolated Lordhowea insularis (Benth.) B.Nord. (Schmidt-Lebuhn et al., 2020). In doing this, however, the puzzle was shifted to a deeper phylogenetic level, because Lordhowea and the new genus Scapisenecio appear to form two lineages seemingly on a grade below the northern hemisphere Adenostylinae Benth. \& Hook.f. It is possible that this unexpected pattern is the result of relatively ancient dispersal events and extinctions. A wellsampled, time-calibrated backbone phylogeny of the tribe will be required to infer the most probable scenario.

The Celmisia group in Astereae shows biogeographic connections to New Zealand and subantarctic islands (Wagstaff et al., 20 I I). The Vittadinia group likewise ranges across Australia and New Zealand but also the Pacific, with Tetramolopium most speciose in New Guinea and Hawai'i . The most thoroughly studied case in the tribe may, however, be Lagenophora (Sancho et al., 20 I 5), which parallels Abrotanella in both its Gondwanan pattern and the absence of a pappus that would facilitate wind dispersal.

Several other tribes show striking disjunctions of Australian species from their areas of origin, again with divergence dates too recent for vicariance to be feasible. A single species of Mutisieae Cass., Trichocline spathulata (A.Cunn. ex DC.) J.H.Willis, occurs in southwestern Western Australia. Despite 


\section{A model of}

\section{evolution}

The Senecio pinnatifolius A. Rich. (formerly S

lautus auct. non G.Forst. ex Willd.) complex

comprises several varieties ranging in

ecological adaptation from coastal dunes to the

alpine zone. It is used as a model system for

the study of evolution and speciation by the

lab of Daniel Ortiz-Barrientos at the University

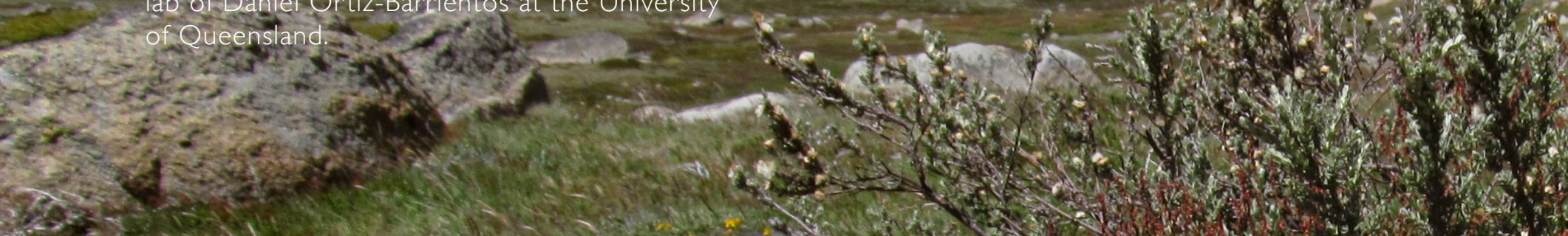

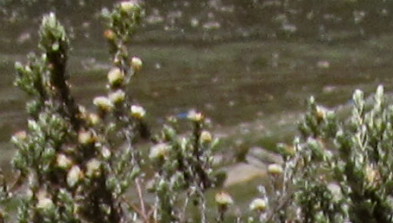

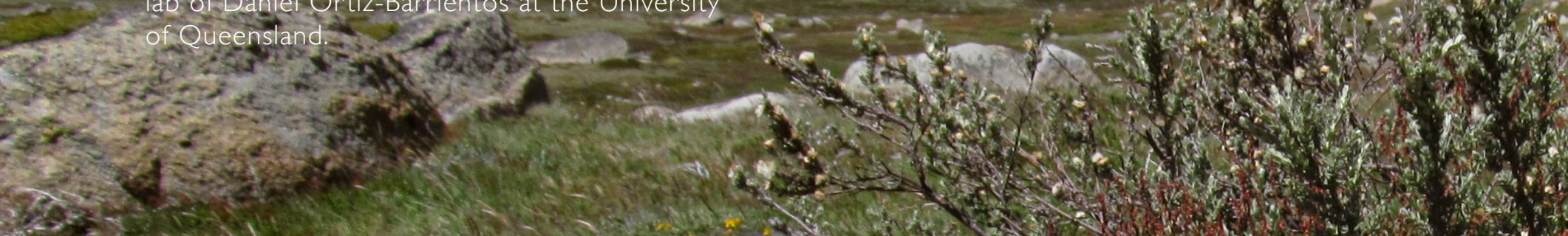

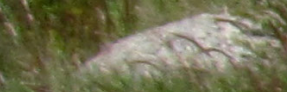

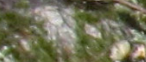

(6)

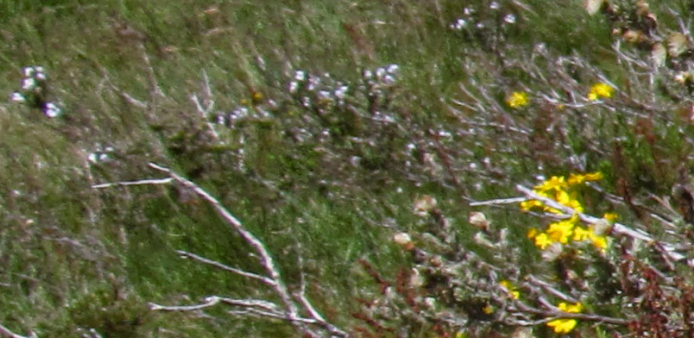

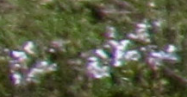

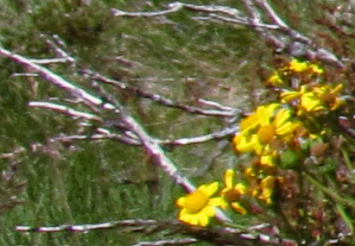

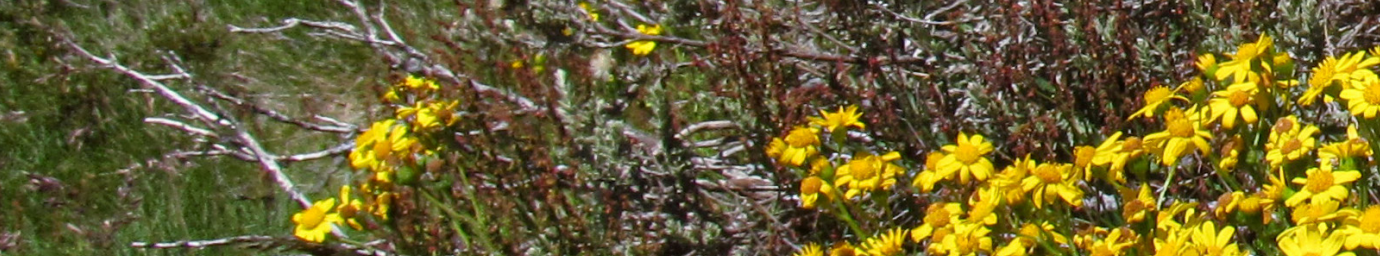

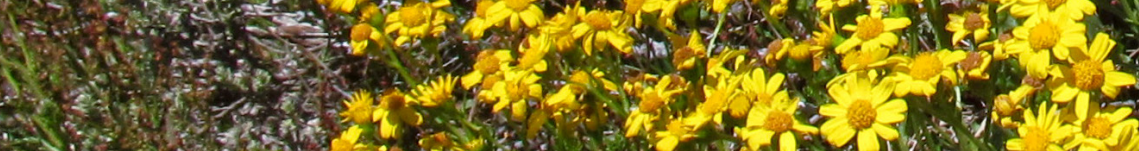

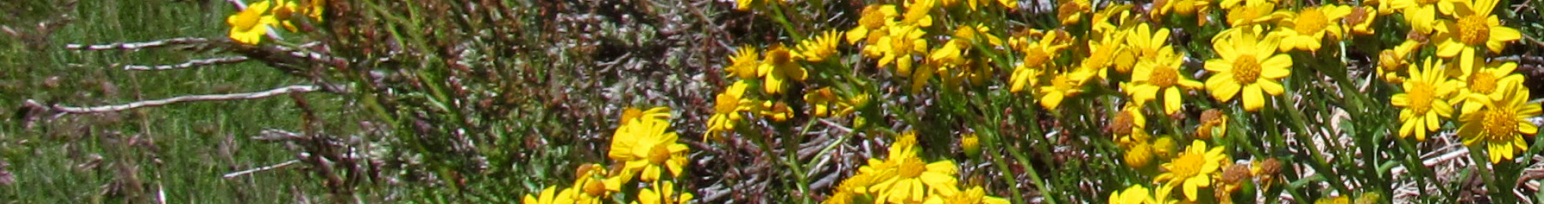

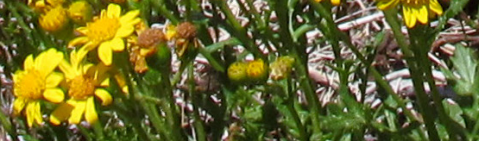

ate

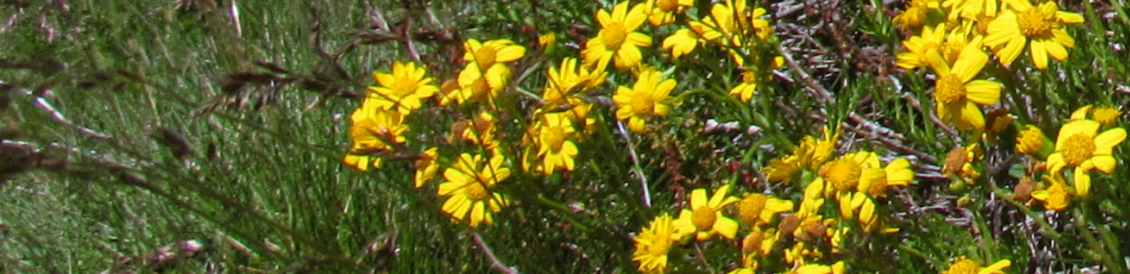

a.t.

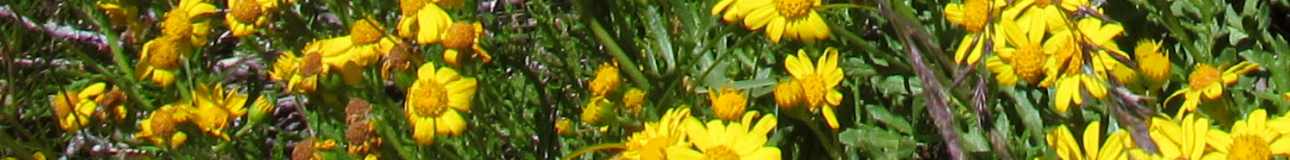

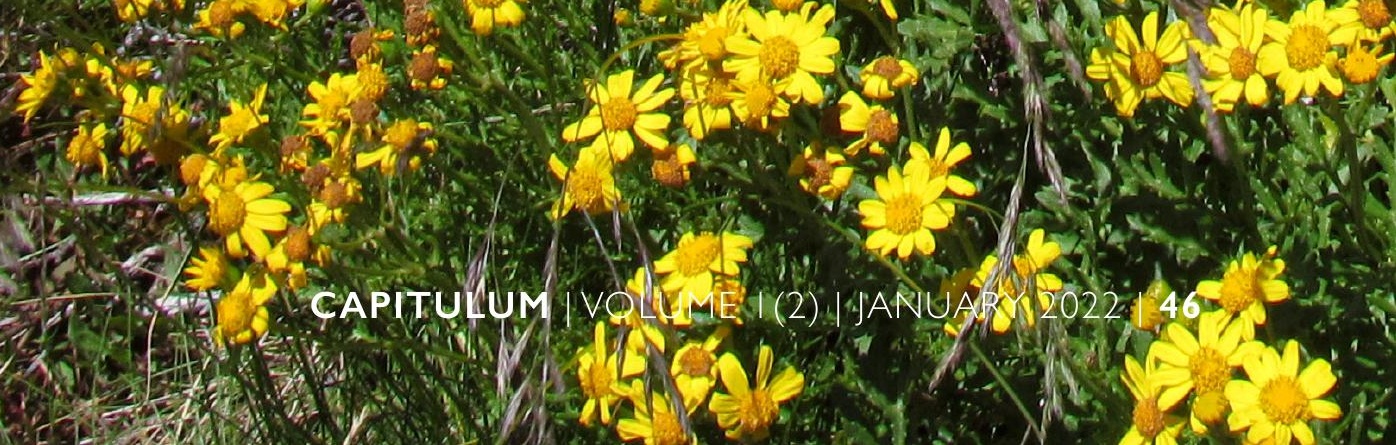


the diversity of Cardueae on other continents, only two potentially native species are found in Australia, Hemisteptia lyrata (Bunge) Fisch. \& C.A.Mey and Rhaponthicum australe (Gaudich.) Sojak. Cymbonotus is deeply nested inside otherwise southern African Arctotideae Cass. (Funk et al., 2007). In Cichorieae, Microseris (Figure 6D) is North American and Australasian (Vijverberg et al., 1999). A comprehensive biogeographic study on the ancestral range evolution of Picris (Figure 6E) inferred its dispersal to Australia from Asia (Slovák et al., 2018). Several genera of the Heliantheae alliance occur with few species in Australia, often in the northern half of the continent.

\section{THE WAY FORWARD}

Although it can be assumed that the vast majority of Asteraceae have already been discovered, remote parts of Australia remain insufficiently explored. Most herbarium specimens were collected close to major cities, whereas the eastern half of the largest state, Western Australia, is so poorly sampled that it is difficult to even estimate the local species numbers (Schmidt-Lebuhn et al., 2012). As the Australian taxonomic community enacts it Decadal Plan (www.taxonomyaustralia.org.au/decadal-plan), targeted collecting in under-collected areas will be critical to complete the inventory of continental biodiversity.

As of the writing of this manuscript, the Australian Plant Census accepted 48 phrase name species in Asteraceae. These are are placeholder names following the format "Rhodanthe sp. Point Lookout (J.J.Bruhl 2078) NE Herbarium" and are used to enable the conservation of and communication about species while their formal scientific publication is in preparation (Barker, 2005). Unfortunately, it can often take a decade or more before a phrase name species is validated. It is possible that this is partly due to the taxonomic impediment, i.e. lack of taxonomists. It is also possible, however, that the custom of using phrase names actually discourages their validation, as taxonomists might be worried either about 'scooping' the person who registered the phrase name or about being scooped themselves if they invested the time, because that person may already have a manuscript under review. Whatever the cause, it would be desirable to accelerate the description of new species that are already known to exist.
A greater gap than species discovery are, however, genus-level studies. Several important genera have not been comprehensively revised, including some of the largest, Olearia and Ozothamnus. Even genera recently having seen taxonomic changes and additions of species are frequently lacking identification keys covering all their species (e.g., Pycnosorus). Many existing keys are outdated, and with the exception of the Cassinia group (keys.lucidcentral.org/keys/ $\mathrm{v} 3$ /cassinia/), interactive identification tools using terminology accessible to non-taxonomists are all but non-existent. Collections technicians, researchers, conservation managers, biosecurity practitioners, and the general public therefore find it difficult to reliably identify Asteraceae specimens and would benefit from the publication of additional modern, electronic identification tools and field guides.

On the other hand, phylogenetic studies have been produced at an increasing rate in recent years. Publications of well-sampled phylogenies covering major groups of interest such as Olearia and Celmisia, Brachyscome, and Coronidium and Xerochrysum are currently in preparation. The Australian Angiosperm Tree of Life (AAToL) initiative in the Genomics for Australian Plants consortium (GAP, www. genomicsforaustralianplants.com) has produced sequence capture data for one species of each genus. In this case, the over-splitting of Gnaphalieae genera means that a very densely sampled backbone phylogeny will soon be available to guide future research.

Significant gaps in our knowledge of phylogenetic relationships will be filled in the next few years. In Gnaphalieae, a particular focus will be the Angianthus clade, where major changes in the circumscription of genera can be expected due to the large number of potential apomorphic segregates. Genomic data will be required to resolve conflicting ribosomal and chloroplast signals in Senecioneae.

Once species-level data have become available for all major groups, attention can turn towards evolutionary questions, ideally in the context of time-calibrated phylogenies: How was the Australian Asteraceae flora assembled in time and space? What was the impact of the aridification of the continent on patterns of diversification? What are key innovations that drove adaptive radiations into arid and alpine areas? 


\section{ACKNOWLEDGMENTS}

I thank Brendan Lepschi for proof-reading and helpful comments on an earlier version of the manuscript and two anonymous reviewers for their comments.

\section{LITERATURE CITED}

Anderberg, A.A. 1990. Nablonium is a congener of Ammobium (Asteraceae: Gnaphalieae). Telopea 4: 129-|35.

Anderberg, A.A. 1991. Taxonomy and phylogeny of the tribe Gnaphalieae (Asteraceae). Opera Bot. 104: I-195.

Barker, W.R. 2005. Standardising informal names in Australian publications. Aust. Syst. Bot. Soc. Newsl. I22: I I-12.

Bayer, R.J. 200I. Xerochrysum Tzvelev, a pre-existing generic name for Bracteantha Anderb. \& Haegi (Asteraceae: Gnaphalieae). Kew Bull. 1013-1015.

Bayer, R.J., Greber, D.G. \& Bagnall, N.H. 2002. Phylogeny of Australian Gnaphalieae (Asteraceae) based on chloroplast and nuclear sequences, the trnL intron, trnL/trnF intergenic spacer, matK, and ETS. Syst. Bot. 27: 80 I-8I4.

Bean, A.R. 20 I I a. A taxonomic revision of Pterocaulon section Monenteles (Labill.) Kuntze (Asteraceae: Inuleae-Plucheinae). Austrobaileya 8: 280-334.

Bean, A.R. 20l lb. Two new species of Pluchea Cass. (Asteraceae: Plucheinae) from Queensland, Australia. Austrobaileya 8: 340-346.

Bean, A.R. 20/3a. Reinstatement and revision of Sphaeromorphaea DC. and Ethuliopsis F.Muell. (Asteraceae: Plucheinae). Austrobaileya 9: 30-59.

Bean, A.R. 20l3b. Three new species of Pluchea Cass. (Asteraceae: Inuleae-Plucheinae) from northern Australia. Austrobaileya 9: 66-74.

Bean, A.R. 2020a. A taxonomic revision of Olearia elliptica DC. (Asteraceae: Astereae) with the description of two new species O. fulgens A.R.Bean and O. praetermissa (P.S.Green) A.R.Bean. Austrobaileya 10: 656-662.

Bean, A.R. \& Mathieson, M.T. 20l5. Olearia cuneifolia A.R.Bean \& M.T.Mathieson (Asteraceae: Astereae), a new species from Queensland. Austrobaileya 9: 404-407.

Bean, T. 2020b. A taxonomic revision of Camptacra N.T.Burb. (Asteraceae: Astereae). Austrobaileya 10: 564-575.

Bergh, N.G. \& Linder, P.H. 2009. Cape diversification and repeated out-of-southern-Africa dispersal in paper daisies (Asteraceae-Gnaphalieae). Mol. Phylogenet. Evol. 5I:5-18.
Breitwieser, I. \& Ward, J.M. 1997. Transfer of Cassinia leptophylla (Compositae) to Ozothamnus. N. Z. J. Bot. 35: I25|28. https://doi.org/I 0.1 080/0028825X.1997.10410675

Burbidge, N. 1982.A revision of VittadiniaA.Rich. (Compositae) together with reinstatement of Eurybiopsis DC. and description of a new geunus, Camptacra. Brunonia 5: 1-72.

Cross, E.W., Quinn, C.J. \& Wagstaff, S.J. 2002. Molecular evidence for the polyphyly of Olearia (Astereae: Asteraceae). Plant Syst. Evol. 235: 99-120. https://doi.org/I0.1007/s00606002-0198-9

Davis, G.L. 1952. Revision of the genus Calotis R.Br. Proc. Linn. Soc. New South Wales 77: 146-188.

Denda, T., Watanabe, K., Kosuge, K., Yahara, T. \& Ito, M. 1999. Molecular phylogeny of Brachycome (Asteraceae). Plant Syst. Evol. 217: 299-31 I. https://doi.org/ I 0. I 007/BF00984372

Dennis, R.J. \& Walsh, N.G. 2010. A revision of the Leucochrysum albicans (Asteraceae: Gnaphalieae) complex. Muelleria 28: |22-|35.

Dunlop, C.R. 1981. A revision of the genus Streptoglossa (Asteraceae: Inuleae). J. Adel. Bot. Gard. 3: |67-|82.

Dunlop, C.R. \& Orchard, A.E. 20 I 5. Blumea. Pp. 372-382 in: Flora of Australia, vol. 37. Melbourne: ABRS/CSIRO.

Edwards, R.D., Cantley, J.T., Chau, M.M., Keeley, S.C. \& Funk, V.A. 2018. Biogeography and relationships within the Melanthera alliance: A pantropical lineage (Compositae: Heliantheae: Ecliptinae). Taxon 67: 552-564. https://doi. org/ I 0. I2705/673.6

Everett, J. \& Doust, A.N.L. 1992a. Four new Australian species of Craspedia sens. strict. (Asteraceae: Gnaphalieae). Telopea 5: 35-38.

Everett, J. \& Doust, A.N.L. 1992b. New species and a new combination in Pycnosorus (Asteraceae: Gnaphalieae). Telopea 5: $39-43$.

Everett, J. \& Thompson, J. 1992. New alpine and subalpine species in Craspedia sens. strict. (Asteraceae: Gnaphalieae). Telopea 5: 45-5I.

Ford, K.A., Ward, J.M., Smissen, R.D., Wagstaff, S.J. \& Breitwieser, I. 2007. Phylogeny and biogeography of Craspedia (Asteraceae: Gnaphalieae) based on ITS, ETS and psbA-trnH sequence data. Taxon 56: 783-794.

Funk, V.A., Chan, R. \& Holland, A. 2007. Cymbonotus (Compositae:Arctotideae,Arctotidinae): an endemic Australian genus embedded in a southern African clade. Bot. J. Linn. Soc. 153: I-8. https://doi.org/ | 0. I | | |/j. | 095-8339.2007.00596.x 
Gott, B. 1983. Murnong - Microseris scapigera: A study of a staple food of Victorian Aborigines. Aust. Aborig. Stud. Canberra 2-18. https://doi.org/| 0.33 | 6/ielapa.287863328982808

Gray, M. \& Given, D.R. 1999. New species and a new combination in Australian Celmisia (Asteraceae-Astereae). Aust. Syst. Bot. 12: 20 I-206. https://doi.org/ 10.1071/sb98009

Himmelreich, S., Breitwieser, I. \& Oberprieler, C. 2012. Phylogeny, biogeography, and evolution of sex expression in the southern hemisphere genus Leptinella (Compositae, Anthemideae). Mol. Phylogenet. Evol. 65: 464-48I. https://doi. org/ | 0.10 | 6/j.ympev.2012.07.001

Holland, A.E. 1994. Two new species of Rutidosis DC. (Asteraceae: Gnaphalieae) from Queensland. Austrobaileya 4: 199-203.

Holland, A.E. 1999. A new species and a new combination in Rutidosis (Gnaphalieae: Angianthinae: Asteraceae). Austrobaileya 5: 565-572.

Holland, A.E. \& Funk, V.A. 2006. A revision of Cymbonotus (Compositae: Arcotitideae, Arctotidinae). Telopea I I: 266-275.

Holzapfel, S. 1994. A revision of the genus Picris (Asteraceae, Lactuceae) s.I. in Australia. Willdenowia 24: 97-2 18.

Hunger, S. 1996.The Pluchea tetranthera complex (Compositae, Plucheeae) from Australia. Willdenowia 26: 273-282. https://doi. org/ | 0.3372/wi.26.2613

Hunger, S. 1997. A Survey of the Genus Pluchea (Compositae, Plucheeae) in Australia. Willdenowia 27: 207-223.

Jeanes, J.A. 2015. Studies in Podolepis (Asteraceae: Gnaphalieae). Muelleria 33: 21-59.

Jeanes, J.A. 2020. Studies in Podolepis and some related genera (Asteraceae: Gnaphalieae). Muelleria 39: 79-112.

Karis, P.O., Anderberg, A.A. \& Nordenstam, B. 1993. Resurrection and systematic position of Pentalepis F. Muell. (Asteraceae-Heliantheae). Aust. Syst. Bot. 6: I49-153. https:// doi.org/| 0.107|/sb9930149

Keighery, G.J. 2004. Taxonomic notes on the Angianthus drummondii complex (Asteraceae: Gnaphaliinae). Nuytsia 15: 253-260.

King-Jones, S. 200 I. Revision of Pluchea Cass. (Compositae, Plucheeae) in the Old World. Englera 23: 3-136.

Konishi, N., Watanabe, K. \& Kosuge, K. 2000. Molecular systematics of Australian Podolepis (Asteraceae: Gnaphalieae): evidence from DNA sequences of the nuclear ITS region and the chloroplast matK gene. Aust. Syst. Bot. 13: 709-727.
Lander, N.S. \& Barry, R. 1980. A review of the genus Minuria DC. (Asteraceae, Astereae). Nuytsia 3: 22 I-237.

Liew, C.-S., Memory, A.E., Ortiz-Barrientos, D., de Lange, P.J. \& Pelser, P.B. 2018. The delimitation and evolutionary history of the Australasian Lautusoid group of Senecio (Asteraceae: Senecioneae). Taxon 67: | 30-|48. https:// doi.org/10.12705/67/.8

Lowrey, T.K., Quinn, C.J., Taylor, R.K., Chan, R., Kimball, R.T. \& Nardi, J.C.D. 200I. Molecular and morphological reassessment of relationships within the Vittadinia group of Astereae (Asteraceae). Am. J. Bot. 88: 1279-1289.

Lyons, M.N. \& Keighery, G.J. 2015. A new species of Angianthus (Asteraceae: Asteroideae: Gnaphalieae) from the south-west of Western Australia. Nuytsia 25: 125-129.

McDougall, K.L. \& Walsh, N.G. 2008. A conspectus of high-country Craspedia (Asteraceae: Gnaphalieae) of mainland south-eastern Australia. Muelleria 26: 3-10.

Messina, A. \& Walsh, N.G. 2019 . Reinstating Olearia stricta (Asteraceae) for an uncommon shrub from montane regions of SE Australia, and notes on O. ramulosa. Muelleria 37: 109117.

Messina, A., Walsh, N.G., Hoebee, S.E., Green, P.T., Messina, A., Walsh, N.G., Hoebee, S.E. \& Green, P.T. 2013 . A morphological assessment of the Olearia phlogopappa complex (Asteraceae: Astereae). Aust. Syst. Bot. 26: 31-80. https://doi.org/ | 0. I07 |/SBI 2026

Messina, A., Walsh, N.G., Hoebee, S.E., Green, P.T., Messina, A., Walsh, N.G., Hoebee, S.E. \& Green, P.T. 2014. A revision of Olearia section Asterotriche (Asteraceae: Asterae). Aust. Syst. Bot. 27: 199-240. https://doi.org/ I 0.107I/ $\mathrm{SB}|40| 2$

Nesom, G.L. 1998. Full constitution of the Australian genus Pappochroma (Asteraceae: Astereae). Phytologia 85: 276-279.

Nesom, G.L. 2020. New genera from Australian Olearia (Asteraceae: Astereae). Phytoneuron 65: I-94.

Nie, Z.-L., Funk, V.A., Meng, Y., Deng, T., Sun, H. \&Wen, J. 2016. Recent assembly of the global herbaceous flora: evidence from the paper daisies (Asteraceae: Gnaphalieae). New Phytol. 209: 1795-1806. https://doi.org/l0.1 III/ nph. 13740

Nylinder, S., Cronholm, B., de Lange, P.J., Walsh, N. \& Anderberg, A.A. 2013. Species tree phylogeny and character evolution in the genus Centipeda (Asteraceae): Evidence from DNA sequences from coding and non-coding loci from the plastid and nuclear genomes. Mol. Phylogenet. Evol. 68: 239-250. https://doi.org/ I 0. 10 I 6/j.ympev.2013.03.020 
Ohlsen, D.J., Puttock, C.F. \& Walsh, N.G. 20 I0. Phenetic analyses of Ozothamnus hookeri (Asteraceae), with the recognition of a new species, O. cupressoides. Muelleria 28: |10-12|.

Orchard, A.E. 2004a. A reassessment of the genus Haeckeria (Asteraceae: Gnaphalieae), with definition of new species in Cassinia. Aust. Syst. Bot. 17: 447-467.

Orchard, A.E. 2004b. A revision of Cassinia (Asteraceae: Gnaphalieae) in Australia. I. Introduction and generic and infrageneric considerations. Aust. Syst. Bot. 17: 469-48I.

Orchard, A.E. 2004c. A revision of Cassinia (Asteraceae: Gnaphalieae) in Australia. 2. Sections Complanatae and Venustae. Aust. Syst. Bot. 17:505-533.

Orchard, A.E. 2004d. A revision of Cassinia (Asteraceae: Gnaphalieae) in Australia. 3. Section Leptocephalae. Aust. Syst. Bot. 17: 535-565.

Orchard, A.E. 2006. A revision of Cassinia (Asteraceae: Gnaphalieae) in Australia. 5. Additional taxa in section Leptocephalae. Aust. Syst. Bot. 19: |83-19|.

Orchard, A.E. 2013. The Wollastonia/Melanthera/Wedelia generic complex (Asteraceae: Ecliptinae), with particular reference to Australia and Malesia. Nuytsia 23: 337-466.

Orchard, A.E. \& Cross, E.W. 2012. A revision of the Australian endemic genus Pentalepis (Asteraceae: Ecliptinae). Nuytsia 22: 37I-392.

Orchard, A.E. \& Orchard, A.E. 2005. A revision of Cassinia (Asteraceae: Gnaphalieae) in Australia. 4. Section Costatae. Aust. Syst. Bot. 18: 455-47I. https://doi.org/ | 0. I 07 I/SB05002

Orchard, A.E., \& Orchard, A.E. 2009. A revision of Cassinia (Asteraceae: Gnaphalieae) in Australia. 6. Section Cassinia. Aust. Syst. Bot. 22: 344-376. https://doi.org/ I0. I 07 I/SB090 I 8

Rozefelds, A.C., Buchanan, A.M. \& Ford, K.A. 20 I I. New species of Craspedia (Asteraceae: Gnaphalieae) from Tasmania and determination of the identity of C. macrocephala Hook. Kanunnah 4: 93-116.

Salas, M.F.D. \& Schmidt-Lebuhn, A.N. 2018. Integrative approach resolves the taxonomy of the Ozothamnus ledifolius (Asteraceae: Gnaphaliae) species complex in Tasmania, Australia. Phytotaxa 358: | |7-| 38. https://doi.org/| 0.1 I646/ phytotaxa.358.2.2

Sancho, G., Lange, D., J, P., Donato, M., Barkla, J. \& Wagstaff, S.J. 2015. Late Cenozoic diversification of the austral genus Lagenophora (Astereae, Asteraceae). Bot. J. Linn. Soc. 177: 78-95. https://doi.org/ I0.1 I I |/boj. I 2224
Schmidt-Lebuhn, A.N. 2013. Craspedia uniflora G.Forst. (Asteraceae) is a New Zealand endemic and not part of the Australian flora. Austrobaileya 9: |36-139.

Schmidt-Lebuhn, A.N. \& Bovill, J. 2021. Phylogenomic data reveal four major clades of Australian Gnaphalieae (Asteraceae). Taxon n/a. https://doi.org/ I 0.1002/tax.125I0

Schmidt-Lebuhn, A.N., Bruhl, J.J., Telford, I.R.H. \& Wilson, P.G. 20 I 5. Phylogenetic relationships of Coronidium, Xerochrysum and several neglected Australian species of "Helichrysum" (Asteraceae: Gnaphalieae). Taxon 64: 96-109. https://doi.org/| 0.12705/64I.5

Schmidt-Lebuhn, A.N. \& Constable, L. 2013. Phylogenetic relationships of the Australasian shrubby everlastings Ozothamnus and Cassinia (Asteraceae: Asteroideae: Gnaphalieae). Cladistics 29: 574-588. https:// doi.org/l 0.1 | | | //cla. 12007

Schmidt-Lebuhn, A.N., Knerr, N.J. \& Gonzalez-Orozco, C.E. 2012. Distorted perception of the spatial distribution of plant diversity through uneven collecting efforts: the example of Asteraceae in Australia. J. Biogeogr. 39: 20722080. https://doi.org/ | 0.1 | | | /j. I365-2699.20 I 2.02756.x

Schmidt-Lebuhn, A.N., Puttock, C.F., Davis, R.W. \& Wege, J. 2018. Two new species of Ozothamnus (Asteraceae: Gnaphalieae) from Australia. Phytotaxa 336: 190-196. https://doi.org/ 10.1 | 646/phytotaxa.336.2.6

Schmidt-Lebuhn, A.N., Zeil-Rolfe, I., Lepschi, B. \& Gooden, B. 2020. Expansion of Lordhowea, and a new genus for scapose, alpine Australian species of Senecioneae (Asteraceae). Taxon 69: 756-777. https://doi.org//0.1002/ $\operatorname{tax} .1232 \mid$

Short, P.S. 1983. A revision of Angianthus sensu lato (Compositae: Inuleae: Gnaphaliinae). Muelleria 5: |43-I85.

Short, P.S. 1985. A revision of Actinobole Fenzl ex Endl. (Compositae: Inuleae: Gnaphaliinae). Muelleria 6: 9-22.

Short, P.S. 1986. A revision of Pogonolepis Steetz (Compositae: Inuleae:Gnaphaliinae). Muelleria 6: 237-253.

Short, P.S. 1990. A revision of the genus Chthonocephalus Steetz (Compositae: Inuleae: Gnaphaliinae). Muelleria 7: 225-238.

Short, P.S. 1995. A revision of Millotia (AsteraceaeGnaphalieae). Aust. Syst. Bot. 8: I-47.

Short, P.S. 2000. Notes on Myriocephalus Benth. s. lat. (Asteraceae: Gnaphalieae). Aust. Syst. Bot. 13: 729-738. 
Short, P.S. 2014a. A taxonomic review of Brachyscome Cass. s.lat. (Asteraceae: Astereae), including descriptions of a new genus, Roebuckia, new species and new infraspecific taxa. J. Adel. Bot. Gard. 28: I-219.

Short, P.S. 20 I 4b. Roebuckiella P.S.Short, nom. nov., a replacement name for Roebuckia P.S.Short (20|4), with new combinations. J. Adel. Bot. Gard. 28: 22 I-222.

Short, P.S. 2015. Notes concerning the classification of species included in Calocephalus R. Br. s.lat. and Gnephosis Cass. s.lat. (Asteraceae: Gnaphalieae), with descriptions of new genera and species. J. Adel. Bot. Gard. 29: 147-220.

Short, P.S., \& Anderberg, A.A. 1995. Cladistic analysis of Millotia (Asteraceae-Gnaphalieae). Aust. Syst. Bot. 8: 49-55.

Slovák, M., Kučera, J., Lack, H.W., Ziffer-Berger, J., Melicharková, A., Záveská, E. \& Vd’ačný, P. 2018. Diversification dynamics and transoceanic Eurasian-Australian disjunction in the genus Picris (Compositae) induced by the interplay of shifts in intrinsic/extrinsic traits and paleoclimatic oscillations. Mol. Phylogenet. Evol. I19: 182-195. https://doi. org/10.1016/j.ympev.2017.11.006

Smissen, R.D., Bayer, R.J., Bergh, N.G., Breitwieser, I., Freire, S.E., Galbany-Casals, M., Schmidt-Lebuhn, A.N. \& Ward, J.M. 2020. A revised subtribal classification of Gnaphalieae (Asteraceae). Taxon 69: 778-806. https://doi. org/ | 0.1002/tax. I 2294

Susanna, A., Baldwin, B. G. , Bayer, R. J. Bonifacino, J. M., Garcia-Jacas, N., Keeley, S. C., Mandel, J., Ortiz, R. S., Robinson, H. \& T. F. Stuessy. 2020. The classification of the Compositae: a tribute to Vicki Ann Funk (1947-2019). Taxon 69: 807-814.

Swenson, U., Nylinder, S. \& Wagstaff, S.J. 2012. Are Asteraceae 1.5 billion years old? A reply to Heads. Syst. Biol. 61: 522-532. https://doi.org/ | 0.1093/sysbio/syr 121

Thompson, I.R. 2004a. Taxonomic studies of Australian Senecio (Asteraceae): 2. The shrubby, discoid species and the allied radiate species Senecio linearifolius. Muelleria 20:67-I 10.

Thompson, I.R. 2004b. Taxonomic studies of Australian Senecio (Asteraceae): 3. Radiate, arid region species allied to $S$. magnificus and the radiate, alpine species $S$. pectinatus. Muelleria 20: $111-138$.

Thompson, I.R. 2004c. Taxonomic studies of Australian Senecio (Asteraceae): I. the disciform species. Muelleria 19: |01-214.

Thompson, I.R. 2005a.Taxonomic studies of Australian Senecio (Asteraceae): 4. A revision of Senecio glossanthus and recognition of an allied species with long ligule. Muelleria 2 l: 3-21.
Thompson, I.R. 2005b. Taxonomic studies of Australian Senecio (Asteraceae): 5. The S. pinnatifolius/S. lautus complex. Muelleria 21:23-76.

Thompson, I.R. 2006. A taxonomic treatment of tribe Senecioneae (Asteraceae) in Australia. Muelleria 24:5 I-1 10.

Vijverberg, K., Mes, T.H.M. \& Bachmann, K. 1999. Chloroplast DNA evidence for the evolution of Microseris (Asteraceae) in Australia and New Zealand after longdistance dispersal from western North America. Am. J. Bot. 86: | 448-| 463. https://doi.org/| 0.2307/2656926

Wagstaff, S.J. \& Breitwieser, I. 2004. Phylogeny and classification of Brachyglottis (Senecioneae, Asteraceae): an example of a rapid species radiation in New Zealand. Syst. Bot. 29: | 003-10 | 0.https://doi.org/| 0. | 600/036364404245099 |

Wagstaff, S.J., Breitwieser, I. \& Ito, M. 20। I. Evolution and biogeography of Pleurophyllum (Astereae, Asteraceae), a small genus of megaherbs endemic to the subantarctic islands. Am. J. Bot. 98: 62-75. https://doi.org//0.3732/ ajb. 1000238

Walsh, N.G. 200I. A revision of Centipeda (Asteraceae). Muelleria 15:33-64.

Walsh, N.G. 2004. Olearia brevipedunculata (Asteraceae): a new species from alpine areas of mainland Australia. Muelleria 19:95-100.

Walsh, N.G. 2014. A revision of the Coronidium scorpioides (Asteraceae: Gnaphalieae) complex. Muelleria 32: 16-33.

Walsh, N.G. 2016. A name for Murnong (Microseris: Asteraceae: Cichorioideae). Muelleria 34: 63-67.

Wang, J. \& Bean, A.R. 2019. A taxonomic revision of Lagenophora Cass. (Asteraceae) in Australia. Austrobaileya 10: 405-442.

Watanabe, K., Kosuge, K., Shimamura, R., Konishi, N., Taniguchi, K., Watanabe, K., Kosuge, K., Shimamura, R., Konishi, N. \& Taniguchi, K. 2006. Molecular systematics of Australian Calotis (Asteraceae: Astereae). Aust. Syst. Bot. | 9: | 55-|68. https://doi.org/| 0. I07|/SB0500 |

Weber, X.A. \& Schmidt-Lebuhn, A.N. 20I5. Generic boundaries of Leucochrysum and Waitzia (Asteraceae: Gnaphalieae). Aust. Syst. Bot. 28: 203-2I 8.

Wilson, A. 2015. Flora of Australia, vol. 37, Asteraceae I. Melbourne: ABRS/CSIRO.

Wilson, P.G. 1989. A revision of the genus Hyalosperma (Asteraceae: Inuleae: Gnaphaliinae). Nuytsia 7: 75-101. 


\section{Schmidt-Lebuhn | HEAD TOPICS}

Wilson, P.G. 1992a. The classification of Australian species currently included in Helipterum and related genera (Asteraceae : Gnaphalieae) : Part I. Nuytsia 8: 379-438.

Wilson, P.G. 1992b. The classification of Australian species currently included in Helipterum (Asteraceae: Gnaphalieae): part 2. Leucochrysum. Nuytsia 8: 439-446.

Wilson, P.G. 1992c. The classification of some Australian species currently included in Helipterum and Helichrysum (Asteraceae: Gnaphalieae): part 3. Anemocarpa and Argentipallium, two new genera from Australia. Nuytsia 8: 447460.

Wilson, P.G. 1992d. The classification of the genus Waitzia Wendl. Nuytsia 8: 461-477.
Wilson, P.G. 200 I. Leiocarpa, a new Australian genus of the Asteraceae tribe Gnaphalieae. Nuytsia 13: 595-605.

Wilson, P.G. 2008. Coronidium, a new Australian genus in the Gnaphalieae (Asteraceae). Nuytsia 18: 295-329.

Wilson, P.G. 20 I 6. A taxonomic treatment of Chrysocephalum apiculatum and C. semipapposum (Asteraceae: Gnaphalieae). Nuytsia 27: 33-73.

Wilson, P.G. 2017. An examination of the Australian genus Xerochrysum (Asteraceae: Gnaphalieae). Nuytsia 28: I I-38. 